\title{
FELLOWSHIPS FOR SCIENTIFIC AND MEDICAL RESEARCH
}

\section{Leverhulme Research Fellowships}

$\mathrm{T}$ HE following Leverhulme Research Fellowships, tenable for varying periods up to two years, have recently been awarded for the research indicated : T. Burton Brown (Armenian archæology in pre-Christian and early Christian periods); IV. H. B Court, lecturer in economic history, University of Birmingham (India and British economic policy in the past century); Dr. W. Cule Davies, lecturer in chemistry, University College, Cardiff (studies of the organic compounds of nitrogen, phosphorus and arsenic); Dr. R. M. Davies, lecturer in physics, University College, Aberystwyth (experimental in. vestigations on turbulent flow in an air-tunnel); $R$. Dennell, assistant lecturer in zoology, Imporial College of Science and Technology, London (structure and physiology of the luminous organs of Atlantic deep-sea Crustacea); Prof. G. R. Driver, professor of Semitic philology, Oxford (languages and customs of the Semitic East); Dr. R. W. Firth, reader in anthropology, University of London (social structure and economic organization of rural Malays); D. Ll. Griffiths, clinical assistant, Orthopxdic Department, Ianchester Royal Infirmary (comparison of radiological and histological features in bone tumours); A. E. Ingham, University lecturer in mathematics, Cambridge (analytical theory of numbers); Dr. B. Jones, lecturer in chemistry, University of Sheffield (a study of reaction kineties in solution); Dr. F. D. Klingender, investigator, Research Group, Political and Economic Planning (a survey of the social rela! tions of scientific research in Great Britain); Dr. S. Maccoby, assistant master, Wolsingham Grammar School, Bishop Auckland, Durham (the character and influence of Radicalism, 1768-1832); Dr. E. B. Maxted, special lecturer in catalysis, University of Bristol (studies in catalyst poisoning); D. A. O'Duffy, research and development assistant, Bahrein Petroleum Company (lubrication problems at high temperatures and pressures); Dr. A. H. Smith, reader in English, University of London (scientific methods of dealing with damaged, imperfect and illegible medieval manuscripts); L. F. Taylor, late research lecturer in Indo-Chinese ethnography and linguistics, University College, Rangoon (an ethnographical and linguistic survey of Burma); Miss M. L. Tildesley, chairman of the Comité de Standardisation de la Technique anthropologique, London (definition, measurements and classification of anthropometric characters); Dr. WV. A. Waters, lecturer in chemistry, University of Durham (mechanisms of reactions involving free organic radicals); Prof. E. L. E. Wheatcroft, professor of electrical engineering, University of Leeds (mechanism of development of electric sparks with reference to lightning discharges); Miss D. Whitelock, fellow and tutor in the English language. St. Hilda's College, Oxford (an edition of the Historia Eliensis, Parts I and II).

\section{Rockefeller Travelling Fellowships iN MEDICINE}

The following Rockefeller travelling fellowships have been arrarded by the Medical Research Council for the academic year 1939-40: G. Blackburn, demonstrator in anatomy, St. Bartholomew's Hospital, London ; Dr. J. C. Dick, assistant pathologist, University of Glasgow and Glasgow Royal Infirmary; Dr. J. L. Henderson, assistant, Department of Child Life and Health, University of Edinburgh; Dr. R. S. Illingworth, resident medical assistant and clinical pathologist, Hospital for Sick Children, Great Ormond Street, London; R. M. Kark, formerly demonstrator in pathology and registrar to medical out-patients, Guy's Hospital, London; E. P. Sharpey-Schafer, first assistant, Department of Medicine, British Postgraduate Medical School, London.

All these fellows propose to work at centres in the United States.

\section{Travelling Fellowships in Tuberculosis}

The Medical Research Council has awarded Dorothy Temple Cross Research Fellowships to the following candidates intending to study problems of tuberculosis at centres abroad, during tho academic year $1939-40$ : Dr. R. R. Henderson, resident assistant physician, St. Thomas's Hospital, London ; A. H. II. Siddons, chief assistant, Genito-Urinary Department, St. George's Hospital, London; Dr. J. M. Vaizey, medical first assistant and registrar, London Hospital.

\section{BeIT FELLOWSHIPS}

Beit Fellowships for Scientific Research, tenable at the Imperial College of Science and Technology during the academic year 1939-40 have been awarded as follows : Extensions of fellowships already satisfactorily held for one year to : Dr. E. J. Harris, for the continuation of research on organic poroxides in relation to hydrocarbon combustion, under the direction of Prof. A. C. G. Egerton; J. L. O. G. Michiels, for the continuation of research on the fission of uranium by neutrons, under the direction of Prof. G. P. Thomson. New fellowships tenable for one year but renewable for a second to: E. S. J. Hatcher, for research on hybrid vigour in the tomato, under the direction of Prof. W. Brown; D. P. Pielou, for research on the olfactory reactions of insects, under the direction of Prof. J. IV. Munro; A. L. G. Rees, for research on problems of a physico. chemical nature concerned with compounds of germanium, under the direction of Prof. H. V. A. Briscoo.

\section{UNIVERSITY EVENTS}

SHeFFIELD.-The following appointments have been made: Dr. R. D. Haworth, to the chair of chemistry, in succession to Prof. R. P. Linstead, resigned; Dr. Wilson Smith, to the chair of bacteriology, in succession to the late Prof. J. W. Edington; Dr. Brymmor Jones, at present a lecturer in chemistry, to bo lecturer on organic chemistry ; F. G. HanneH, as assistant lecturer in geography; Dr. Andrew Wilson, as assistant lecturer in pharmacology; Mr. R. Halle, as a research assistant in tho Department of Glass Technology. 